\title{
Gejala Heat Strain pada Pekerja Pembuat Tahu di Kawasan Kamboja Kota Palembang
}

\author{
Dicky Zulhanda ${ }^{1}$, Mona Lestari ${ }^{1 *}$, Desheila Andarini $^{1}$, Novrikasari ${ }^{1}$, Yuanita Windusari ${ }^{2}$, \\ Poppy Fujianti ${ }^{1}$
}

${ }^{1}$ Bidang Ilmu Keselamatan dan Kesehatan Kerja, Fakultas Kesehatan Masyarakat, Universitas Sriwijaya, J1.Palembang Prabumulih Km.32 Indralaya Sumatera Selatan 30662, Indonesia

${ }^{2}$ Bidang Ilmu Kesehatan Lingkungan, Fakultas Kesehatan Masyarakat, Universitas Sriwijaya, Jl.Palembang Prabumulih Km.32 Indralaya Sumatera Selatan 30662, Indonesia

*Corresponding author : mona_lestari@unsri.ac.id

Info Artikel:Diterima 23 Januari 2021; Disetujui 25 Juli 2021 ; Publikasi 1 Oktober 2021

Cara sitasi (Vancouver): Zulhanda D, Lestari M, Andarini D, Novrikasari N, Windusari Y, Fujianti P. Gejala Heat Strain pada Pekerja Pembuat Tahu di Kawasan Kamboja Kota Palembang. Jurnal Kesehatan Lingkungan Indonesia [Online]. 2021 Oct;20(2):120-127. https://doi.org/10.14710/jkli.20.2.120-127.

\begin{abstract}
ABSTRAK
Latar belakang: Pabrik tahu merupakan salah satu tempat kerja yang berpotensi menimbulkan iklim kerja panas. Hal ini tidak terlepas dari penggunaan api sebagai media produksi yang dapat menyebabkan seseorang mengalami heat strain. Untuk itu, penelitian ini bertujuan untuk mengetahui proporsi gejala heat strain pada pekerja pembuat tahu dan faktor apa yang paling mempengaruhi gejala heat strain tersebut.

Metode: Penelitian ini menggunakan desain cross sectional study dan penetapan sampel menggunakan teknik total sampling. Sampel dalam penelitian ini berjumlah 54 orang yang berasal dari enam pabrik tahu. Analisis data penelitian menggunakan uji chi square untuk analisis bivariat dan uji regresi logistik berganda untuk analisis multivariat.

Hasil: Hasil penelitian menunjukkan proporsi gejala heat strain pada pekerja sebesar $64,8 \%$ dan diketahui bahwa adanya hubungan antara iklim kerja panas $(p$-value $=0,008)$, usia $(p$-value $=0,014)$, dan konsumsi air minum $(p$-value $=0,002)$ dengan gejala heat strain, dan tidak adanya hubungan antara lama kerja $(p$-value = $0,077)$ dengan gejala heat strain. Hasil analisis multivariat menunjukkan bahwa terdapat hubungan antara iklim kerja panas dengan gejala heat strain $(p$-value $=0,004)$ setelah dikontrol oleh variabel perancu.

Simpulan: Hasil penelitian diketahui bahwa iklim kerja panas merupakan faktor yang paling mempengaruhi gejala heat strain pada pekerja pembuat tahu di Kawasan Kamboja Kota Palembang. Pemilik pabrik tahu dapat melakukan perbaikan ventilasi dan memasang plafon di pabrik, serta menyediakan fasilitas air minum untuk memenuhi kebutuhan air 2,8 liter/hari bagi pekerja.
\end{abstract}

Kata kunci: Iklim kerja panas; heat strain; pekerja pembuat tahu; api tungku

\section{ABSTRACT}

Title: Heat Strain Symptoms in Tofu Production Workers in Kamboja Area of Palembang City

Background: Tofu industry is one of workplaces which has potential in creating hot working climate. This industry cannot be separated from the use of fire as one of production element where exposure to fire may cause workers to experience heat strain. This study aimed to determine the proportion of heat strain symptoms in tofu workers and what factors most influence the symptoms of heat strain.

Method: This study used cross sectional study design and samples were determined by using total sampling technique. Samples in this study amounted to 54 workers from six tofu making businesses. Analysis for study data was using chi-square test for bivariate analysis and multiple logistic regression test for multivariate analysis. 
Result: The study showed that the proportion for workers with heat strain symptoms was 64.8\%. It was found that there was a correlation between hot work climate (p-value $=0.008)$, age (p-value $=0.014)$, and water consumption ( $p$-value $=0.002)$ with heat strain symptoms. Meanwhile, there is no correlation between work length ( $p$-value $=0.077)$ with heat strain symptoms. The result of multivariate analysis showed that there was a correlation between hot working climate and heat strain symptoms ( $p$-value $=0.004)$ after control applied from confounding variables.

Conclusion: The result showed that the hot working climate was the most influencing factor for the symptoms of heat strain on tofu workers. Tofu factory owners can repair ventilation and install ceilings in the factory. Besides, provide drinking water facilities to meet 2.8 liters/day for workers' water needs.

Keywords: Hot working climate; heat strain; tofu producer workers; stove fire

\section{PENDAHULUAN}

Produktivitas kerja dapat diraih saat para pekerja merasa nyaman dengan lingkungan kerja. Iklim kerja ataupun suhu udara merupakan salah satu faktor yang dapat mempengaruhi kondisi lingkungan kerja. ${ }^{1}$ Untuk itu, pemilik usaha sudah seharusnya memperhatikan kondisi iklim lingkungan kerja. Menurut Permenaker Nomor 5 Tahun 2018, pekerja akan nyaman bekerja dengan suhu ruangan berkisar $23^{\circ} \mathrm{C}$ hingga $26^{\circ} \mathrm{C}$ dan kelembaban $40 \%$ hingga $60 \%$. Namun pada dasarnya manusia memiliki kemampuan untuk beradaptasi di lingkungan yang lebih dingin maupun lebih panas dengan batasan tertentu. ${ }^{2}$

Batasan iklim kerja panas yang dapat diperkenankan pada pekerja dipengaruhi oleh beban kerja dan persentase jam kerja setiap jam. ${ }^{1}$ Pajanan panas yang berlebih tidak hanya mengganggu kenyamanan pekerja, namun juga dapat berdampak terhadap kesehatan pekerja. Peningkatan suhu tubuh, peningkatan denyut nadi, dan pengeluaran keringat berlebih merupakan gejala awal yang akan timbul saat seseorang terpajan panas berlebih. Beberapa gejala tersebut (heat strain) merupakan bentuk upaya seseorang untuk menstabilkan suhu tubuh. ${ }^{3}$

Ketidakmampuan sistem termoregulasi untuk menjaga kestabilan suhu tubuh yang disebabkan pajanan panas berlebih akan menyebabkan timbulnya tekanan panas yang berakibat pada penyakit terkait panas. $^{4}$ Beberapa penyakit akibat panas yang terjadi dapat bersifat akut maupun kronis. Penyakit akut dapat berupa dehidrasi, heat rashes, heat cramps, heat syncope, heat exhaustion, dan heat stroke. Sedangkan dampak kronis pada seseorang yang terpajan panas terjadi secara tidak langsung, dimana pajanan panas berlebih akan memperparah kondisi penyakit seseorang hingga menyebabkan kerusakan permamen pada beberapa organ seperti saluran pernapasan, jantung, ginjal, hati, bahkan otak., ${ }^{3,5,6}$

Data dari Central of Disease Control (CDC) Amerika Serikat pada tahun 2001 hingga 2010 di 20 negara bagian terdapat 28.000 kasus rawat inap heat stress illness, didapatkan juga hubungan yang signifikan antara jumlah rawat inap heat stress illness dengan rata-rata indeks suhu panas bulanan di setiap negara bagian $(\mathrm{p}<0,0001))^{7}$ Selain itu, dari metaanalysis yang dilakukan oleh Flouris et. al (2018) diketahui bahwa $35 \%$ pekerja yang mengalami occupational heat strain, 30\% pekerja kehilangan produktivitas, dan $15 \%$ pekerja mengalami penyakit ginjal atau cidera ginjal akut, diketahui juga bahwa pekerja yang bekerja pada suhu diatas $22^{\circ} \mathrm{C}$ atau $24,8^{\circ} \mathrm{C}$ berisiko 4,01 kali untuk mengalami occupational heat strain dibandingkan denan pekerja di kondisi thermoneutral. ${ }^{8}$ Sementara, terdapat juga beberapa penelitian di Indonesia yang menunjukkan dampak iklim kerja panas terhadap pekerja. Dari beberapa penelitian menunjukkan bahwa seluruh pekerja konstruksi yang berjumlah 57 pekerja mengalami heat strain dengan index level sedang hingga sangat tinggi ${ }^{9}$ dan $35,8 \%$ operator Pembangkit Listrik Tenaga Diesel (PLTD) mengalami heta strain pada zona kuning (alarm category). ${ }^{10}$

Penggunaan api pada proses produksi tahu memiliki peranan yang penting sebagai salah satu media untuk memasak. Kapasitas produksi yang cukup besar dapat mempengaruhi skala penggunaan api. Hal ini secara tidak langsung akan menyebabkan iklim lingkungan kerja menjadi panas. Kondisinya akan semakin parah jika ruang kerja tidak disertai dengan sistem ventilasi yang memadai, pengaturan sirkulasi udara yang baik serta penggunaan tirai pada bagian ruang yang terkena matahari secara langsung. ${ }^{11}$ Hal ini dapat menyebabkan berbagai keluhan yang dapat dialami pekerja, seperti dehidrasi, kelelahan, dan perasaan tidak nyaman, serta dikhawatirkan dapat juga menimbulkan gejala heat strain hingga heat related illness jika tidak diatasi sesegera mungkin. Seperti yang telah diungkapkan dalam penelitian Irawati, diketahui bahwa suhu rata-rata di area produksi pabrik tahu $\mathrm{X}$ dan $\mathrm{Y}$ yaitu $35,6^{\circ} \mathrm{C}$ dan $35,5^{\circ} \mathrm{C}$, serta $61,7 \%$ responden mengalami keluhan heat strain. $^{12}$

Kawasan Kamboja merupakan salah satu pusat produksi tahu di Kota Palembang. Hasil survei awal menunjukkan bahwa penggunaan api yang cukup besar pada proses perebusan bubur kedelai. Hal ini dipengaruhi oleh besarnya tungku perebusan guna memenuhi kapasitas produksi harian. Selain itu, beberapa pabrik tahu memiliki kondisi bangunan yang kurang memadai, seperti tidak adanya ventilasi dan beratapkan seng. Hal ini dikhawatirkan dapat menyebabkan pekerja mengalami gejala heat strain bahkan berakibat terjadinya heat related illness. Oleh karena itu, penelitian ini dilakukan untuk mengetahui 
proporsi gejala heat strain pada pekerja pembuat tahu di Kawasan Kamboja Kota Palembang dan faktor apa yang paling mempengaruhi gejala heat strain tersebut.

\section{MATERI DAN METODE}

Penelitian ini merupakan penelitian kuantitatif dengan desain cross sectional. Penelitian ini bertujuan untuk mengetahui proporsi gejala heat strain pada pekerja pembuat tahu di Kawasan Kamboja Kota Palembang dan faktor apa yang paling mempengaruhi gejala heat strain tersebut. Populasi dalam penelitian berjumlah 54 orang yang berasal dari enam pabrik tahu di Kawasan Kamboja Kota Palembang. Penetapan sampel responden dalam penelitian ini menggunakan teknik total sampling yang berarti seluruh populasi merupakan sampel penelitian.

Penetapan jumlah titik pengukuran iklim kerja panas ditetapkan berdasarkan SNI 16-7061-2004. ${ }^{13}$ Titik pengukuran pada pabrik tahu bervariasi, terdapat tiga pabrik tahu yang memiliki tiga titik pengukuran dan tiga lainnya memiliki dua titik pengukuran. Namun hasil akhir pengukuran pada seluruh pabrik tahu akan menghasilkan dua hasil pengukuran saja, hal ini disebabkan oleh seluruh pekerja pada area penggilingan merangkap kerja pada area perebusan. Sehingga hasil pengukuran pajanan iklim kerja panas pada pekerja tersebut akan menjadi nilai rata-rata.

Metode pengumpulan data dalam penelitian ini adalah pengukuran langsung dan wawancara dengan menggunakan kuesioner. Pengukuran langsung dilakukan untuk mengukur iklim kerja panas dan gejala heat strain. Pengukuran iklim kerja panas menggunakan Heat Stress Monitor. Iklim kerja panas diukur sebanyak dua kali pada seluruh pabrik yaitu pada pukul 09.00 WIB dan 11.30 WIB. Penetapan Nilai Ambang Batas (NAB) iklim kerja panas disesuaikan dengan alokasi waktu kerja dan beban kerja yang diterima oleh pekerja. Penetapan beban kerja didapatkan melalui perhitungan laju metabolik koreksi. Perhitungan tersebut menggunakan berat badan pekerja dan nilai laju metabolik observasi yang disesuaikan dengan jenis aktivitas pekerja. Aktivitas para pekerja pabrik tahu saat produksi adalah berdiri sambil melakukan pekerjaan ringan dengan lengan dan sesekali berjalan, sehingga termasuk dalam kategori beban kerja ringan dengan nilai laju metabolik observasi sebesar $180 .{ }^{14}$ Berikut rumus perhitungan laju metabolik koreksi:

Laju Metabolik $_{(\text {korerssi) }}=\frac{\text { Berat Badan Pekerja }(\mathrm{Kg})}{70(\mathrm{Kg})} \times$ Laju Metabolik $_{(\text {observasi) }}$

Sementara, pengukuran gejala heat strain menggunakan rumus penghitungan Physiological Strain Index (PSI). Penghitungan PSI dilakukan melalui hasil pengukuran suhu tubuh dengan thermometer dan pengukuran denyut nadi dengan perabaan arteri radialis. Rumus perhitungan PSI sebagai berikut:
$P S I=5 \frac{(T-T o)}{39,5-T o}+5 \frac{(H R-H R o)}{(180-H R o)}$

$\begin{array}{ll}\text { Keterangan: } \\ \mathrm{T} & \text { : Suhu tubuh saat bekerja }\left({ }^{\circ} \mathrm{C}\right) \\ \mathrm{To} & \text { : Suhu tubuh sebelum bekerja }\left({ }^{\circ} \mathrm{C}\right) \\ \mathrm{HR} & \text { : Denyut jantung saat bekerja }(\mathrm{bpm}) \\ \mathrm{HRo} & \text { : Denyut jantung sebelum bekerja } \\ & (\mathrm{bpm})\end{array}$

Angka 5 merupakan nilai konstanta yang telah ditetapkan, angka 39,5 merupakan standar suhu tubuh tertinggi, dan angka 180 merupakan standar denyut jantung tertinggi. Pekerja akan dinyatakan mengalami heat strain jika memiliki hasil perhitungan PSI di atas dua $(>2)$, hasil tersebut menunjukkan adanya peningkatan denyut nadi dan suhu tubuh pada pekerja. ${ }^{15}$ Pengukuran PSI dilakukan pada pekerja yang terpajan panas dan diukur diakhir waktu/shift kerja agar memperoleh suhu tubuh maksimal.

Wawancara dilakukan dengan meggunakan kuesioner yang bertujuan untuk mendapatkan informasi terkait usia, lama kerja, dan kebiasaan konsumsi air minum. Kemudian, analisis data dilakukan mulai dari analisis univariat untuk menggambarkan proporsi gejala heat strain dan variabel lainnya, analisis bivariat melalui uji chi square untuk menguji hubungan antara variabel independen (iklim kerja panas, usia, lama kerja, dan kebiasaan konsumsi air minum) dengan variabel dependen (gejala heat strain), p-value $<\alpha(0,05)$ artinya ada hubungan yang signifikan antara kedua variabel. Terakhir, analisis multivariat melalui uji regresi logistik berganda untuk menganalisis faktor apa yang paling mempengaruhi gejala heat strain pada pekerja pembuat tahu di Kawasan Kamboja Kota Palembang.

\section{HASIL DAN PEMBAHASAN}

Mengacu pada Peraturan Menteri Ketenagakerjaan Republik Indonesia Nomor 5 Tahun 2018, Nilai Ambang Batas (NAB) iklim kerja panas ditentukan berdasarkan pengaturan waktu kerja setiap jam dan beban kerja. Untuk penelitian ini, diketahui alokasi waktu kerja dan istirahat 75 sampai $100 \%$ dan beban kerja ringan, sehingga NAB iklim kerja panas yang diperkenankan pada pabrik tahu di Kawasan Kamboja Kota Palembang adalah $31^{\circ} \mathrm{C} .{ }^{1}$ Penetapan beban kerja yang ringan didapatkan melalui perhitungan laju metabolik koreksi. Hasil perhitungan laju metabolik koreksi pada seluruh pekerja pabrik tahu berada dalam kategori beban kerja ringan $(<$ 235). Nilai rata-rata laju metabolik koreksi dari seluruh pekerja tahu adalah 154, dengan nilai minimal 95 dan nilai maksimal 219.

Hasil pengukuran iklim kerja panas menunjukkan bahwa suhu di seluruh pabrik tahu berada di atas $\mathrm{NAB}\left(>31^{\circ} \mathrm{C}\right)$, sehingga tidak dapat dikelompokkan menjadi $\geq \mathrm{NAB}$ dan $<\mathrm{NAB}$. Untuk itu, dilakukan uji normalitas kolmogorov smirnov untuk memperoleh cut off point baru untuk variabel iklim 
kerja panas. Hasil uji normalitas menunjukkan nilai signifikansi (sig.) sebesar 0,000 (sig. < 0,05), artinya distribusi data tidak normal, sehingga cut off point baru untuk variabel iklim kerja panas menggunakan median yaitu $34,9^{\circ} \mathrm{C}$ (Tabel 1).

Tabel 1. Hasil Uji Statistik Deskriptif Variabel Iklim Kerja Panas

\begin{tabular}{lcccc}
\hline \multicolumn{1}{c}{ Variabel } & Median & SD & Min & Max \\
\hline $\begin{array}{l}\text { Iklim Kerja } \\
\text { Panas }\end{array}$ & 34,900 & 1,6982 & 33,8 & 39,8 \\
\hline
\end{tabular}

Tabel 2 menunjukkan bahwa dari 54 pekerja, mayoritas pekerja mengalami gejala heat strain $(64,8 \%)$ dan $48,1 \%$ pekerja terpajan iklim kerja panas di atas $34,9^{\circ} \mathrm{C}$. Selain itu, diketahui juga bahwa usia pekerja paling banyak $\leq 40$ tahun $(53,7 \%)$, dengan lama kerja paling banyak $\leq 4$ jam per hari $(72,2 \%)$, dan kebiasaan konsumsi air minum didominasi oleh pekerja yang mengkonsumsi air minum kurang dari 2,8 liter per hari $(57,4 \%)$.
Tabel 2. Hasil Analisis Univariat

\begin{tabular}{lcc}
\hline \multicolumn{1}{c}{ Variabel } & $\mathbf{n}=\mathbf{5 4}$ & $\mathbf{\%}$ \\
\hline Gejala Heat Strain & & \\
$\quad$ Heat Strain & 35 & 64,8 \\
$\quad$ Tidak Heat Strain & 19 & 35,2 \\
Iklim Kerja Panas & & \\
$\quad>34,9^{\circ} \mathrm{C}$ & 26 & 48,1 \\
$\leq 34,9^{\circ} \mathrm{C}$ & 28 & 51,9 \\
Usia & & \\
$\quad>40$ tahun & 25 & 46,3 \\
$\leq 40$ tahun & 29 & 53,7 \\
Lama Kerja & & \\
$\quad>4$ jam/hari & 15 & 27,8 \\
$\quad \leq 4$ jam/hari & 39 & 72,2 \\
Konsumsi Air Minum & & \\
$\quad<2,8$ liter/hari & 31 & 57,4 \\
$\geq 2,8$ liter/hari & 23 & 42,6 \\
\hline
\end{tabular}

Tabel 3 menunjukkan bahwa pekerja yang mengalami heat strain didominasi oleh pekerja yang terpajan iklim kerja panas $>34,9^{\circ} \mathrm{C}(84,6 \%)$ sementara $46,4 \%$ pekerja yang mengalami heat strain adalah pekerja yang terpajan iklim kerja panas $\leq 34,9^{\circ} \mathrm{C}$. Selanjutnya, pekerja yang mengalami heat strain paling banyak berusia di atas 40 tahun $(84,0 \%)$, dengan lama kerja lebih dari 4 jam/hari (86,7\%), dan mengonsumsi air minum kurang dari 2,8 liter per hari $(83,9 \%)$.

Tabel 3. Hasil Analisis Bivariat

\begin{tabular}{|c|c|c|c|c|c|c|}
\hline \multirow{3}{*}{ Variabel } & \multicolumn{4}{|c|}{ Gejala Heat Strain } & \multirow{3}{*}{ p-value } & \multirow{3}{*}{$\begin{array}{l}\text { Nilai PR } \\
(95 \% C I)\end{array}$} \\
\hline & \multicolumn{2}{|c|}{ Ya } & \multicolumn{2}{|c|}{ Tidak } & & \\
\hline & $\mathbf{n}$ & $\%$ & $\mathbf{n}$ & $\%$ & & \\
\hline \multicolumn{7}{|c|}{ Iklim Kerja Panas } \\
\hline$>34,9^{\circ} \mathrm{C}$ & 22 & 84,6 & 4 & 15,4 & \multirow{2}{*}{$0,008 *$} & \multirow{2}{*}{$\begin{array}{c}1,822 \\
(1,185-2,802)\end{array}$} \\
\hline$\leq 34,9^{\circ} \mathrm{C}$ & 13 & 46,4 & 15 & 53,6 & & \\
\hline \multicolumn{7}{|l|}{ Usia } \\
\hline$>40$ tahun & 21 & 84,0 & 4 & 16,0 & \multirow{2}{*}{$0,014^{*}$} & \multirow{2}{*}{$\begin{array}{c}1,740 \\
(1,150-2,632)\end{array}$} \\
\hline$\leq 40$ tahun & 14 & 48,3 & 15 & 51,7 & & \\
\hline \multicolumn{7}{|l|}{ Lama Kerja } \\
\hline$>4$ jam/hari & 13 & 86,7 & 2 & 13,3 & \multirow{2}{*}{0,077} & \multirow{2}{*}{$\begin{array}{c}1,536 \\
(1,094-2,158)\end{array}$} \\
\hline$\leq 4 \mathrm{jam} / \mathrm{hari}$ & 22 & 56,4 & 17 & 43,6 & & \\
\hline \multicolumn{7}{|l|}{$\begin{array}{l}\text { Konsumsi Air } \\
\text { Minum }\end{array}$} \\
\hline$<2,8$ liter/hari & 26 & 83,9 & 5 & 16,1 & \multirow{2}{*}{$0,002^{*}$} & \multirow{2}{*}{$\begin{array}{c}2,143 \\
(1,258-3,651)\end{array}$} \\
\hline$\geq 2,8$ liter/hari & 9 & 39,1 & 14 & 60,9 & & \\
\hline
\end{tabular}

Analisis bivariat menunjukkan adanya hubungan yang signifikan antara iklim kerja panas, usia, dan konsumsi air minum dengan timbulnya gejala heat strain pada pekerja pabrik tahu ( $p$-value $=0,008 ; p$ value $=0,014 ; p$-value $=0,002)$. Sementara, tidak ada hubungan antara lama kerja dengan gejala heat strain pada pekerja pabrik tahu ( $p$-value $=0,077)$, meskipun nilai PR menunjukkan signifikansi $(95 \% \mathrm{CI}=1,094-$
2,158). Secara statistik, nilai lower 1,094 dianggap tidak terlalu signifikan karena nilainya yang mendekati 1, hal ini juga dibuktikan dengan nilai $p$ value yang tidak menunjukkan adanya hubungan. Namun, variabel lama kerja bisa menjadi salah satu faktor risiko yang mempengaruhi gejala heat strain pada pekerja pabrik tahu apabila variabel ini tidak diintervensi. Akan adanya efek pajanan kumulatif jika 
pekerja dibiarkan secara terus-menerus terpajan panas dalam waktu yang lama. Selain itu, setelah dianalisis bersama dengan faktor lain (analisis multivariat), variabel lama kerja dinyatakan sebagai variabel perancu (Tabel 4).

Hasil uji statistik menyatakan bahwa pekerja yang terpajan iklim kerja panas $>34,9^{\circ} \mathrm{C}$ lebih berisiko 1,822 kali untuk mengalami gejala heat strain dibandingkan dengan pekerja yang terpajan terpajan iklim kerja panas $\leq 34,9^{\circ} \mathrm{C}(95 \% \mathrm{CI}=1,185-2,802)$. Pekerja yang berusia di atas 40 tahun lebih berisiko 1,740 kali untuk mengalami gejala heat strain dibandingkan dengan pekerja yang berusia $\leq 40$ tahun $(95 \%$ CI $=1,150-2,632)$. Pekerja yang mengonsumsi air minum kurang dari 2,8 liter per hari lebih berisiko 2,143 kali untuk mengalami gejala heat strain dibandingkan dengan pekerja yang yang mengonsumsi air minum $\geq 2,8$ liter per hari $(95 \% \mathrm{CI}=$ $1,258-3,651)$.

Tabel 4 menunjukkan bahwa variabel usia, lama kerja, dan konsumsi air minum merupakan variabel perancu. Hasil analisis multivariat menunjukkan bahwa variabel iklim kerja panas merupakan faktor yang paling berpengaruh terhadap timbulnya gejala heat strain pada pekerja pembuat tahu di Kawasan Kamboja Kota Palembang setelah dikontrol oleh variabel perancu $(p$-value $=0,004)$. Pekerja pembuat tahu yang terpajan iklim kerja panas berlebih memiliki risiko 39 kali lebih tinggi untuk mengalami gejala heat strain $(95 \% \mathrm{CI}=3,170-468,547)$.

Tabel 4. Hasil Analisis Multivariat

\begin{tabular}{lccc}
\hline \multicolumn{1}{c}{ Variabel } & p-value & PR Crude & 95\% CI \\
\hline Iklim Kerja Panas & 0,004 & 38,546 & $3,170-468,547$ \\
Usia & 0,018 & 18,561 & $1,650-209,835$ \\
Lama Kerja & 0,020 & 27,388 & $1,672-448,502$ \\
Konsumsi Air & 0,008 & 13,237 & $1,948-89,930$ \\
Minum & & & \\
\hline
\end{tabular}

Hasil penelitian menunjukkan bahwa terdapat hubungan yang signifikan antara iklim kerja panas dengan gejala heat strain pada pekerja pembuat tahu. Hal ini sejalan dengan penelitian Istiqoma (2019) yang menunjukkan adanya hubungan signifikan antara iklim kerja dengan risiko heat strain pada pekerja dengan nilai $p$-value $=0,000 .{ }^{16}$ Hasil penelitian ini juga senada dengan penelitian Maknun (2019) yang menyatakan adanya hubungan signifikan antara iklim kerja dengan kejadian heat strain pada pekerja dengan nilai $p$-value $=0,011 .^{17}$

Iklim kerja panas yang timbul pada seluruh pabrik tahu di Kawasan Kamboja disebabkan oleh penggunaan api saat proses perebusan bubur kedelai, hal ini juga didukung oleh kondisi bangunan yang kurang memadai. Hasil pengamatan yang dilakukan saat penelitian diketahui bahwa seluruh pabrik tahu yang menjadi lokasi penelitian menggunakan material atap seng sebagai atap bangunan tanpa penggunaan plafon sehingga menyebabkan suhu di area produksi semakin meningkat saat siang hari. Hal ini selaras dengan penelitian Fatimah et. al (2019) mengenai beberapa jenis atap rumah di Desa Badaun Tapin Utara didapatkan bahwa dari ketiga jenis atap yang diamati, seng merupakan jenis atap yang memiliki suhu ruangan rata-rata tertinggi sebesar $32,1^{\circ} \mathrm{C}$ dibandingkan dengan asbes dan daun. ${ }^{18}$ Pada penelitian Antou (2013) didapatkan hasil penilaian reduksi panas dari tiga jenis atap yang diantaranya yaitu seng, beton, dan tanah liat menunjukkan bahwa atap seng memiliki kemampuan reduksi panas terburuk $\left(110 \mathrm{~W} / \mathrm{m}^{2}\right){ }^{19}$

Ventilasi yang kurang memadai pada beberapa pabrik tahu menjadi faktor lain yang menyebabkan timbulnya iklim kerja panas. Terdapat pabrik tahu yang hanya menggunakan pintu keluar masuk ruangan sebagai sirkulasi udara. Sirkulasi udara merupakan salah satu faktor yang harus diperhatikan pada bangunan di daerah tropis seperti Indonesia. Ventilasi sebagai media sirkulasi udara akan mengatur kondisi thermal ruangan melalui pemenuhan kebutuhan oksigen yang masuk dan pembuangan hawa panas ke luar ruangan. ${ }^{20}$ Maka dari itu, menurut Peraturan Menteri Kesehatan Republik Indonesia Nomor 48 Tahun 2016, suatu ruangan harus memiliki ventilasi sekurang-kurangnya $15 \%$ dari luas lantai ruangan. Peletakan posisi ventilasi akan lebih ideal jika diletakkan pada kedua sisi ruangan, dikarenakan sirkulasi udara akan lebih efektif pada sistem ventilasi silang. $^{21}$

Penggunaan ventilasi dapat dilakukan melalui dua cara, yaitu ventilasi alami dan ventilasi buatan. Namun jika suatu ruangan tidak memungkinkan untuk dibuatkan ventilasi alami, penggunaan ventilasi buatan berupa exhaust fan dan blower dapat dijadikan solusi untuk mengatasi iklim kerja panas pada ruang produksi. Cara kerja exhaust fan dan blower yang menghisap uap panas dan udara kotor dari dalam menuju luar ruangan dapat memperlancar sirkulasi udara pada ruang produksi tahu. Peletakan exhaust fan dapat diletakkan pada sisi ruangan maupun atap ruangan. ${ }^{22}$ Pada penelitian Ichsan dan Zulwisli (2020) didapatkan hasil pengujian exhaust fan pada rumah berkonsep greenhouse, penggunaan exhaust fan yang diiringi dengan kipas angin dapat membantu pembuangan uap panas dari suatu ruangan. Pengunaan kedua alat tersebut menghasilkan penurun suhu yang signifikan pada rumah tersebut, dalam waktu 551 detik suhu ruang yang semula berada pada $31^{\circ} \mathrm{C}$ menurun hingga $27^{\circ} \mathrm{C}$. Saat ditambahkan alat humidifier, kualitas udara pada rumah tersebut semakin membaik, dalam waktu 75 detik kelembapan rumah tersebut meningkat dari yang semula bernilai 87 meningkat hingga $95 .^{23}$

Peningkatan suhu tubuh dapat terjadi secara konveksi saat suhu lingkungan mengalami peningkatan. Hal ini serupa dengan terjadinya pendinginan tubuh yang berkeringat saat terkena hembusan kipas angin. Jika hembusan kipas angin dapat menurunkan suhu tubuh, maka hawa panas yang berasal dari proses produksi tahu dapat meningkatkan suhu tubuh. ${ }^{24}$ Di sisi lain, Korpus Ruffini yang 
berfungsi sebagai reseptor rangsangan panas akan mengantarkan impuls menuju hipotalamus. Hipotalamus akan mengaktifkan thermostat guna melakukan pelepasan panas tubuh melalui keringat. ${ }^{25}$ Vasodilatasi pembuluh darah perifer dan aktivasi kelenjar keringat merupakan bentuk respon yang dilakukan hipotalamus. Vasodilatasi pembuluh darah perifer akan menyebabkan beban jantung meningkat, hal ini terjadi guna memenuhi kebutuhan darah pada area tersebut. Peningkatan beban kerja jantung senada dengan peningkatan detak jantung, dan hal ini dapat dirasakan melalui perabaan denyut nadi. ${ }^{26}$ Kondisi tubuh yang terus menerus memompa darah akibat pelebaran pembuluh darah pada pekerja yang terpajan panas dapat berdampak terhadap kesehatan jantung maupun produktivitas kerja.

Penelitian ini juga menunjukkan bahwa terdapat hubungan yang signifikan antara usia dengan gejala heat strain pada pekerja pembuat tahu. Hal ini selaras dengan penelitian Maknun (2019) yang menunjukkan adanya hubungan antara usia dengan kejadian heat strain pada pekerja dengan nilai $p$-value $=0,005 .^{17}$ Namun pada penelitian Fadhilah (2014) diketahui bahwa tidak terdapat hubungan antara usia dengan kejadian heat strain pada pekerja pembuat kerupuk $(p$-value $=0,702)$ karena kedua kelompok umur dalam penelitian ini menerima pajanan tekanan panas yang relatif sama sehingga tidak terlihat perbedaan kejadian heat strain pada kedua kelompok umur tersebut. ${ }^{27}$ Pada penelitian Strydom (1971) telah dilakukan pendataan kasus heat stroke pada pekerja tambang emas di Afrika Selatan dalam rentang waktu 5 tahun. Hasil penelitian tersebut didapatkan gambaran kejadian heat stroke yang sering muncul seiring dengan pertambahan usia pekerja. Meskipun populasi pekerja yang berusia diatas 40 tahun hanya $10 \%$, tetapi $50 \%$ kasus fatal heat stroke berasal dari pekerja yang berusia di atas 40 tahun. $^{28}$

Proses penuaan pada manusia akan menyebabkan penurunan kinerja jantung, hal ini pada umumnya dapat terjadi saat usia seseorang melebihi 40 tahun. Penurunan kinerja jantung menyebabkan kemampuan pemompaan darah ke seluruh tubuh tidak efektif. Hal ini mengganggu sistem termoregulasi yang berfungsi melepas panas tubuh saat terpajan panas. ${ }^{29}$ Sulitnya pelepasan panas tubuh pada pekerja yang semakin tua dapat juga disebabkan oleh gangguan kelenjar keringat. Gangguan yang terjadi dapat berupa penurunan produksi kolagen yang dihasilkan fibroblas. Hal ini menyebabkan kulit pada pekerja yang berusia tua sulit berkeringat akibat terhambatnya aliran air ke bagian epidermis. ${ }^{30}$ Sehingga, dapat disimpulkan bahwa proses penuaan akan menyebabkan penurunan detak jantung dan peningkatan suhu tubuh. Namun pada penelitian ini, terdapat beberapa pekerja yang berusia diatas 40 tahun mengalami peningkatan detak jantung yang cukup signifikan saat terpajan panas. Hasil ini diduga akibat beberapa pekerja tersebut memiliki rentang usia yang tidak terlalu jauh dari 40 tahun. Namun pada dasarnya sebagian besar pekerja yang mengalami gejala heat strain didominasi oleh pekerja yang mengalami peningkatan suhu tubuh yang signifikan akibat gangguan sistem termoregulasi.

Hasil penelitian menunjukkan bahwa tidak ada hubungan antara lama kerja dengan gejala heat strain pada pekerja pembuat tahu. Meskipun tidak berhubungan, secara statistik diketahui bahwa terdapat $86,7 \%$ pekerja yang mengalami gejala heat strain dengan lama kerja $>4$ jam/hari. Hal ini menunjukkan bahwa apabila variabel lama kerja tidak segera diintervensi, variabel ini akan menjadi faktor risiko sebagai akibat dari pajanan kumuliatif. Hasil ini sejalan dengan penelitian Istiqoma (2019) yang menunjukkan tidak adanya hubungan antara lama kerja dengan gejala heat strain namun akan menjadi faktor risiko jika tidak diintervensi, terlihat dari data statistik yang menunjukkan terdapat $100 \%$ yang mengalami gejala heat strain dengan lama kerja $>8$ jam/hari. ${ }^{16}$

Semakin lama seseorang terpajan panas, maka semakin besar risiko untuk mengalami gejala heat strain. Beberapa pekerja akan menunjukkan peningkatan suhu tubuh dan denyut nadi setelah dua jam bekerja. Namun gejala heat strain yang signifikan akan terasa setelah masuk ke 3 jam kerja, dan hal ini akan bertambah pada jam selanjutnya. ${ }^{31}$ Maka dari itu, dalam Undang-Undang Republik Indonesia Nomor 13 Tahun 2003 disarankan para pemiliki usaha untuk menetapkan jadwal istirahat karyawan setiap 4 jam kerja tanpa henti, waktu istirahat yang dijadwalkan minimal 30 menit. Namun hasil penelitian menunjukkan hal sebaliknya, pekerja yang mengalami heat strain didominasi oleh pekerja yang bekerja $\leq 4$ jam per hari. ${ }^{32}$ Hasil penelitian diketahui bahwa masih banyaknya pekerja yang memiliki jam kerja $\leq 4$ jam per hari untuk mengalami heat strain dipengaruhi oleh faktor usia, dimana 15 dari 22 orang yang mengalami heat strain berusia diatas 40 tahun. Sebagaimana yang telah dijelaskan sebelumnya bahwa pertambahan usia akan memperlambat proses pelepasan panas pada tubuh seseorang, hal ini diakibatkan oleh terganggunya sistem termoregulasi. Iklim kerja panas juga menjadi faktor yang dapat mempengaruhi kejadian tersebut. Dikarenakan seluruh pabrik tahu memiliki iklim kerja panas lebih dari $31^{\circ} \mathrm{C}$, maka setiap orang berpotensi untuk mengalami gejala heat strain.

Hasil analisis menunjukkan bahwa terdapat hubungan yang signifikan antara konsumsi air minum dengan gejala heat strain pada pekerja pembuat tahu. Hal ini menunjukkan keselarasan dengan hasil penelitian Sutono (2018), didapatkan hubungan antara terpenuhinya kebutuhan konsumsi air minum dengan kejadian heat strain pada pekerja proyek dengan nilai $p$-value $=0,003 .^{33}$ Namun didapatkan hasil sebaliknya pada penelitian Nofianti dan Koesyanto (2019) bahwa tidak adanya hubungan antara konsumsi air minum dengan regangan panas pada pekerja pabrik dengan nilai $p$-value $=0,166$ karena teradapat proporsi yang 
cukup besar pada pekerja yang mengonsumsi air minum yang cukup $(67,6 \%){ }^{34}$

Jantung merupakan organ penting yang mendukung proses pelepasan panas tubuh saat terpajan panas. Proses ini dapat terjadi jika jantung dapat memompa darah ke seluruh tubuh dengan lancar. Namun hal ini akan terhambat jika kebutuhan air dalam darah tidak terpenuhi. Kebutuhan konsumsi air minum pada pekerja yang berada di area panas sebesar $\geq 2,8$ liter per hari, sementara pada pekerja di area tidak panas dianjurkan sekurang-kurangnya 1,9 liter per hari. ${ }^{35,36}$ Air yang berfungsi sebagai pengencer darah akan menyebabkan darah menjadi pekat, hal ini akan menghambat aliran darah dan memperberat kerja jantung. Aliran darah yang terhambat akan memaksa jantung meningkatkan intensitas pemompaan darah, dan detak jantung mengalami peningkatan. ${ }^{37}$ Tidak hanya itu, kurangnya konsumsi air bagi pekerja di lingkungan panas akan menyebabkan timbulnya dehidrasi. Hal ini terjadi akibat tidak adanya pengganti cairan tubuh yang hilang oleh keringat berlebih. ${ }^{38}$ Jika kondisi ini tidak diatasi sedini mungkin, dikhawatirkan pekerja akan mengalami heat related illness hingga serangan jantung. ${ }^{39}$ Maka dari itu, untuk menghindari dehidrasi dan menggantikan cairan tubuh yang hilang saat bekerja di lingkungan panas, pekerja disarankan untuk mengkonsumsi air minimal 2,8 liter per hari.

\section{SIMPULAN}

Hasil penelitian menunjukkan bahwa terdapat $64,8 \%$ pekerja pembuat tahu di Kawasan Kamboja Kota Palembang yang mengalami gejala heat strain. Selain itu, diketahui juga bahwa iklim kerja panas pada seluruh pabrik tahu berada di atas Nilai Ambang Batas (NAB) yang diperkenankan yaitu $31^{\circ} \mathrm{C}$. Hasil analisis multivariat menunjukkan bahwa penyebab utama timbulnya gejala heat strain adalah iklim kerja panas setelah dikontrol oleh variabel usia, lama kerja, dan konsumsi air minum. Pemilik pabrik tahu disarankan untuk memperhatikan kondisi bangunan pada area produksi, menyediakan fasilitas air minum yang mudah dijangkau, serta mengatur waktu istirahat pekerja (minimal 30 menit) setelah bekerja selama 4 jam tanpa henti. Kondisi bangunan diharapkan memiliki sistem ventilasi, baik ventilasi alami maupun buatan, berupa ventilasi alami menyilang pada area produksi dengan luas minimal 15\% dari luas lantai, ventilasi buatan seperti exhaust fan atau blower, dan atau menggunakan plafon guna menjaga iklim kerja ruang produksi. Selain itu, pekerja juga diharapkan untuk membiasakan mengonsumsi air minum minimal 2,8 liter per hari.

\section{PERSETUJUAN KAJI ETIK}

Persetujuan kaji etik diperoleh dari Komisi Etik Penelitian Kesehatan Fakultas Kesehatan Masyarakat Universitas Sriwijaya Nomor: 197/UN9.1.10/KKE/2020 pada tanggal 29 Juni 2020.

\section{DAFTAR PUSTAKA}

1. Kementerian Tenaga Kerja Republik Indonesia. Penerapan K3 Lingkungan Kerja. Peraturan Menteri Tenaga Kerja Nomor 5 Tahun 2018 Republik Indonesia; 2018.

2. Graha AS. Adaptasi Suhu Tubuh Terhadap Latihan dan Efek Cedera di Cuaca Panas dan Dingin. J Olahraga Prestasi. 2010;6(2):123-34.

3. Jacklitsch B, Williams W, Musolin K, Coca A, Kim J-H, Turner N. Criteria for A Recommended Atandard: Occupational Exposure to Heat and Hot Environments [Internet]. Revised Cr. US Department of Health and Human Services. National Institute; 2016. Available

from: https:/www.cdc.gov/niosh/docs/2016-

106/default.html

4. Cheshire WPJ. Thermoregulatory disorders and illness related to heat and cold stress. Auton Neurosci. $\quad 2016 \quad$ Apr;196:91104.https://doi.org/10.1016/j.autneu.2016.01.001

5. Lundgren $\mathrm{K}$, Kuklane $\mathrm{K}$, Gao $\mathrm{C}$, Holmér I. Effects of Heat Stress on Working Populations When Facing Climate Change. Ind Health. 2013;51(1):3-

15.https://doi.org/10.2486/indhealth.2012-0089

6. Africa Research Institute. Between Extremes Health Effects of Heat and Cold. Environ Health Perspect. 2015;123(11):27580.https://doi.org/10.1289/ehp.123-A275

7. Choudhary E, Vaidyanathan A. Heat Stress Illness Hospitalizations-Environmental Public Health Tracking Program, 20 States, 2001-2010 [Internet]. Vol. 63, MMWR Surveillance Summaries. 2014. Available from: https:/www.cdc.gov/mmwr/preview/mmwrhtml/ ss6313a1.htm

8. Flouris AD, Dinas PC, Ioannou LG, Nybo L, Havenith G, Kenny GP, et al. Workers' health and productivity under occupational heat strain: a systematic review and meta-analysis. Lancet Planet Heal. 2018;2(12):e52131.https://doi.org/10.1016/S25425196(18)30237-7

9. Setyaningsih Y, Imas K, Suroto. Working climate, physical workload and its relation to heat strain on construction workers at airport development project. Int J Civ Eng Technol. 2018;9(9):37-42.

10. Ramdan IM, Aguswigati RP, Nuryanto MK, Susanti R. Heat Strains among Diesel Power Plant Operators and Related Factors. Indian J Public Heal Res Dev. 2020;11(7):1329-34.

11. Santoso EI. Kenyamanan Termal Indoor pada Bangunan di Daerah Beriklim Tropis Lembab. Indones Green Technol J. 2012;1(1):13-9.

12. Irawati A. Faktor-Faktor yang Berhubungan dengan Keluhan Heat Strain pada Pekerja Pabrik Tahu X dan Y di Jakarta Selatan Tahun 2019. 
Universitas Pembangunan Nasional "Veteran" Jakarta; 2019.

13. Badan Standardisasi Nasional. SNI 16-70612004 Tentang Pengukuran Iklim Kerja (Panas) dengan Parameter Indeks Suhu Basah dan Bola. 2004.

14. Kementerian Kesehatan Republik Indonesia. Standar dan Persyaratan Kesehatan Lingkungan Kerja Industri. Peraturan Menteri Kesehatan Republik Indonesia Nomor 70 Tahun 2016 Republik Indonesia; 2016.

15. Moran DS, Shitzer A, Pandolf KB. A physiological strain index to evaluate heat stress. Am J Physiol - Regul Integr Comp Physiol. 1998;275(1):R129-

34.https://doi.org/10.1152/ajpregu.1998.275.1.R 129

16. Istiqoma $\mathrm{N}$. Hubungan Iklim Kerja Panas dengan Risiko Heat Strain pada Pekerja Industri Kerupuk Kemplang di Kecamatan Seberang Ulu I Palembang. Fakultas Kesehatan Masyarakat Universitas Sriwijaya; 2019.

17. Maknun YFJ. Hubungan Karakteristik Individu dan Iklim Kerja dengan Kejadian Heat Strain pada Pekerja Bagian Produksi Pabrik Es Lilin Brasil Sokaraja. Universitas Jenderal Soedirman; 2019.

18. Fatimah, Juanda, Santoso I. Jenis Atap, Suhu dan Kelembaban dalam Rumah. J Kesehat Lingkung. 2019;16(1):72732.https://doi.org/10.31964/jkl.v16i1.108

19. Antou RS. Mutu Ekologis Material Penutup Atap. J Perad Sains, Rekayasa dan Teknol. 2013;1(2):71-7.

20. Vidyautami DN, Huboyo HS, Hadiwidodo M. Pengaruh Penggunaan Ventilasi (AC dan non AC) dalam Ruangan terhadap Keberadaan Mikroorganisme Udara di Ruangan Kuliah Jurusan Teknik Sipil Unversitas Diponegoro. J Tek Lingkung. 2015;4(1):1-8.

21. Kementerian Kesehatan Republik Indonesia. Standar Keselamatan dan Kesehatan Kerja Perkantoran. Peraturan Menteri Kesehatan Republik Indonesia Nomor 48 Tahun 2016 Republik Indonesia; 2016.

22. Ellyas A. Rancang Bangun Pengatur Kecepatan Kipas Pembuangan Menggunakan Sensor Asap AF30 Berbasis Mikrokontroler ATMEGA8535. Universitas Diponegoro; 2010.

23. Ichsan M, Zulwisli Z. Pengendalian Suhu dan Kelembapan Greenhouse Menggunakan Exhaust Fan. VoteTEKNIKA J Vocat Tek Elektron dan Inform. 2020;8(4):80-5.

24. Giriwijoyo S, Sidik DZ. Ilmu faal olahraga. Bandung: PT. Remaja Rosdakarya Offset; 2012.

25. Gabriel JF. Fisika Kedokteran. Jakarta: EGC; 2019.

26. Hall JE, Guyton AC. Text book of medical physiology Philadelphia. PA: Elsevier; 2016.
27. Fadhilah R. Faktor-Faktor yang Berhubungan dengan Heat Strain pada Pekerja Pabrik Kerupuk di Wilayah Kecamatan Ciputat Timur Tahun 2014. Universitas Islam Negeri Syarif Hidayatullah Jakarta; 2014.

28. Strydom NB. Age as a causal factor in heat stroke. J South African Inst Min Metall. 1971;72(4):112-4.

29. Berry C, McNeely A, Beauregard K. A guide to preventing heat stress and cold stress. NC Department of Labor Occupational Safety and Health Program; 2011.

30. Haroun MT. Dry skin in the elderly. Geriatr Aging. 2003;6(6):41-4.

31. Adiningsih R. Faktor yang Mempengaruhi Kejadian Heat Strain pada Tenaga Kerja yang Terpapar Panas di PT Aneka Boga Makmur. Indones Occup Saf Heal. 2013;2(2):145-53.

32. Presiden Republik Indonesia. Ketenagakerjaan. Undang-Undang Republik Indonesia No.13 Tahun 2003 Republik Indonesia; 2003.

33. Sutono KIT. Determian Kejadian Heat Strain pada Pekerja Konstruksi di Proyek Pengembangan Bandara Ahmad Yani. Universitas Diponegoro; 2018.

34. Nofianti DW, Koesyanto H. Masa Kerja, Beban Kerja, Konsumsi Air Minum dan Status Kesehatan dengan Regangan Panas pada Pekerja Area Kerja. Higeia J Public Heal Res Dev. 2019;3(4):524-33.

35. Tarwiyanti D, Hartanti RI, Indrayani R. Beban Kerja Fisik dan Iklim Kerja dengan Status Hidrasi Pekerja Unit P2 Bagian (Wood Working 1) WW1 PT. KTI Probolinggo. Pustaka Kesehat. 2020;8(1):60.https://doi.org/10.19184/pk.v8i1.11 200

36. Direktorat Kesehatan Kerja Kementerian Kesehatan RI, Perhimpunan Spesialis Kedokteran Okupasi Indonesia. Pedoman Kebutuhan Cairan Bagi Pekerja agar Tetap Sehat dan Produktif. I. Jakarta; 2014.

37. Hermawan L, Setyo H, Rahayu S. Pengaruh Pemberian Asupan Cairan (Air) Terhadap Profil Denyut Jantung Pada Aktivitas Aerobik. JSSF (Journal Sport Sci Fitness). 2012;1(2):14-20.

38. Hardinsyah S, Razaktaha DB, Effendi MA, Aries M, Lestari KS, Nindya TS, et al. Kebiasaan minum dan status hidrasi pada remaja dan dewasa di dua wilayah ekologi berbeda. Tim THIRST Bogor PERGIZI PANGAN Indones. 2010;53-62.

39. Mintarto E, Fattahilah M. Efek Suhu Lingkungan terhadap Fisiologi Tubuh pada Saat Melakukan Latihan Olahraga. J Sport Exerc Sci. 2019;2(1):9-

13.https://doi.org/10.26740/jses.v2n1.p9-13 